\title{
Role of Peritoneal Ultrafiltration in Heart Failure Treatment
}

\author{
Kalp Yetmezliği Tedavisinde Peritoneal Ultrafiltrasyonun Yeri \\ Tuba Elif Şenel, Egemen Cebeci, Savaş Öztürk \\ University of Health Sciences Haseki Training and Research Hospital, Clinic of Nephrology, Istanbul, Turkey
}

\begin{abstract}
Cardiorenal syndrome (CRS) is a general term that can reflect different clinical conditions in which cardiac and renal dysfunctions coexist. The main pathogenetic mechanisms playing a role in heart failure (HF) and CRS are neurohumoral adaptation, right ventricular dilatation and dysfunction and systemic inflammation. Persistence of these factors cause focal and segmental glomerulosclerosis, and tubulointerstitial fibrosis in the renal parenchyma. Diuretics, beta blockers, reninangiotensin-aldosterone system inhibitors, and vasodilators are the main medical treatments besides conventional approach, such as salt and water restriction and quitting smoking, in $\mathrm{HF}$ treatment. Diuretic resistance is the main problem emerging during diuretic treatments. Two renal replacement treatments have become prominent for removal of excess fluids via ultrafiltration in HF patients with diuretic resistance extracorporeal ultrafiltration with hemodialysis and peritoneal dialysis (PD). Herein, the role of these two ultrafiltration modalities, especially peritoneal ultrafiltration (PUF) in the treatment of HF is discussed. The main studies and advantages of PUF in HF treatment were discussed. Moreover, effects of PD on glomerular filtration rate, hospitalization and mortality were investigated. In conclusion, PD is an alternative cheap, practical and convenient therapy in reducing cardiac volume burden in HF patients who do not respond well to standard treatments and/or require frequent hospitalization.
\end{abstract}

Keywords: Cardiorenal syndrome, heart failure, peritoneal dialysis, ultrafiltration

\section{Öz}

Kardiyorenal sendrom (KRS), kalp ve böbrek fonksiyon bozukluklarının birlikte bulunduğu, farklı klinik tabloları yansıtabilen genel bir terimdir. Kalp yetmezliği (KY) ve KRS'de rol oynayan temel patogenetik mekanizmalar; nörohumoral adaptasyon, sağ ventriküler dilatasyon, ventriküler disfonksiyon ve sistemik enflamasyondur. Süregelen bu faktörler renal parankimde fokal ve segmental glomerüloskleroza, tübülointerstisyel fibrozise neden olmaktadır. KY tedavisinde geleneksel yaklaşımlardan olan tuz ve suyun kısıtlanması, sigaranın bırakılması yanında kullanılan medikal tedavilerin başlıcaları diüretikler, renin-anjiyotensin-aldosteron sistem inhibitörleri, beta blokerler ve vasodilatatörlerdir. Diüretik kullanımı ile ortaya çıkabilecek başlıca problem ise diüretik direncidir. Diüretik direnci olan KY hastalarında fazla sıvının ultrafiltrasyon ile uzaklaştırımasında iki renal replasman tedavisi öne çıkmaktadır ki bunlar, ekstrakorporeal ultrafiltrasyon ve periton diyalizidir (PD). Bu derlemede $\mathrm{KY}$ tedavisinde iki ultrafiltrasyon modalitesinden özellikle peritonel ultrafiltrasyon (PUF) tartışılmıştı. PUF ile ilgili başıı ıca çalışmalar ve PUF'un KY tedavisindeki avantajları irdelenmiştir. Bunun yanı sıra PD'nin glomerüler filtrasyon hızı, hastane yatışı ve mortalite üzerine etkisi araştırımışır. Sonuç olarak PD, standart tedavilere iyi yanıt vermeyen, sık hastaneye yatış gerektiren $\mathrm{KY}$ hastalarında kardiyak volüm yükünü azaltmakta kullanılabilecek ucuz, pratik, uygun bir alternatif tedavidir.

Anahtar Sözcükler: Kardiyorenal sendrom, kalp yetmezliği, periton diyalizi, ultrafiltrasyon
Address for Correspondence/Yazışma Adresi: Tuba Elif Şenel

University of Health Sciences Haseki Training and Research Hospital, Clinic of Nephrology, istanbul, Turkey

Phone: +90 2125294400 E-mail: telifsenel@gmail.com ORCID ID: orcid.org/0000-0002-8637-3582 Received/Geliş Tarihi: 24 September 2017 Accepted/Kabul Tarihi: 28 September 2017
${ }^{\circ}$ Copyright 2017 by The Medical Bulletin of University of Health Sciences Haseki Training and Research Hospital
The Medical Bulletin of Haseki published by Galenos Yayınevi.

Telif Hakkı 2017 Sağlık Bilimleri Üniversitesi Haseki Eğitim ve Arașţıma Hastanesi Haseki Tıp Bülteni, Galenos Yayınevi tarafindan basılmıștir. 


\section{Introduction}

Heart failure (HF) is a medical condition with high mortality rate affecting quality of life adversely with accompanying symptoms and frequent hospitalization. According to the classification by ejection fraction (EF) in current cardiology guidelines, an $\mathrm{EF}$ of $\geq 50 \%$ is defined as $\mathrm{HF}$ with preserved $\mathrm{EF}$, an $\mathrm{EF}<40 \%$ as $\mathrm{HF}$ with reduced $\mathrm{EF}$, and an EF between $40-49 \%$ is classified as "grey zone" (1).

The prevalence is $1-2 \%$ in adult population in developed countries, however, this rate is above $10 \%$ in individuals older than 70 years of age (2-4). In the HF prevalence and predictors in Turkey (HAPPY) study performed in people aged $\geq 35$ years in our country, the prevalence of HF was found to be higher than in western countries (absolute $2.9 \%$, estimated $6.9 \%)(5)$.

The heart-kidney interaction has bidirectional nature. Cardiac diseases are associated with decreased kidney functions and progression in kidney diseases, whereas chronic kidney disease is an independent risk factor for cardiovascular events $(6,7)$. Glomerular filtration rate (GFR) is $<60 \mathrm{~mL} / \mathrm{min}$ in $30-60 \%$ of patients with $\mathrm{HF}$ (811). Renal dysfunction has a greater impact on mortality than impaired cardiac function [EF and New York Heart Association (NYHA) class] in advanced HF patients $(10,12)$.

\section{Cardiorenal Syndrome}

Cardiorenal syndrome (CRS) is a general term that can reflect different clinical conditions in which cardiac and renal dysfunctions coexist. CRS which is an interaction between cardiovascular and renal systems was described by the National Heart, Lung, and Blood Institute in 2004 as worsening of the renal function due to deterioration in left ventricular function (13). However, the classification was made with consideration of chronicity of disease and affected organs, because this description do not include details about different clinical conditions affecting the heart and kidney (14).

- Type 1: Acute worsening of cardiac function leading to renal dysfunction,

- Type 2: Chronic abnormalities in cardiac function leading to renal dysfunction,

- Type 3: Acute worsening of renal function causing cardiac dysfunction,

- Type 4: Chronic abnormalities in renal function leading to cardiac disease (coronary artery disease, heart failure (HF), arrhythmia, etc.),

- Type 5: Systemic conditions (sepsis, diabetes mellitus, systemic lupus erythematosus, etc.) causing simultaneous dysfunction of the heart and kidney.

The main pathogenetic mechanisms playing role in $\mathrm{HF}$ and CRS are listed below;

\section{a) Neurohumoral Adaptation}

The stroke volume decreases as a result of left ventricular dysfunction. As a response, systemic arterial vasoconstriction occurs to protect the perfusion to two vital organs (heart and brain). Whenever afterload increases with vasoconstriction, deterioration in renal perfusion occurs.

Neurohumoral adaptation mechanisms, such as reninangiotensin-aldosterone system (RAAS) and sympathetic nervous system (SNS) activation, and compensatory elevation of antidiuretic hormone (ADH) occur as a response to decreased $\mathrm{EF}$. Blood urea nitrogen (BUN) level might be an indicator of neurohumoral activation in $\mathrm{HF}$ and, a high BUN level is related with mortality in HF (15).

Renin-angiotensin-aldosterone system activation: Tubuloglomerular feedback occurs as a result of decreased amount of sodium reaching the macula densa as a result of decreased renal perfusion pressure in $\mathrm{HF}$. Then vasodilatation of the afferent arteriole occurs while RAAS is activated with secretion of renin from the macula densa. Vasoconstriction of the efferent arteriole occurs via activated RAAS and water and sodium reabsorption increases in the kidney as well.

Antidiuretic hormone: With increase ADH secretion by stimulation of non-osmotic receptors which is response to decreased effective systemic arterial pressure; free water reabsorption increases in collective tubules; simultaneously arterial and venous vasoconstriction occurs via $\mathrm{V} 1 \mathrm{a}$ receptors. At the same time, arterial and venous vasoconstriction occurs via vascular $\mathrm{V} 1 \mathrm{a}$ receptors. As a result of these mechanisms, the cardiac preload and afterload increase (16).

Sympathetic nervous system activation: Baroreceptors located in the aorta are stimulated by decreased stroke volume as a result of $\mathrm{HF}$ and by this way, SNS becomes activated and systematic vasoconstriction occurs.

Ongoing RAAS and SNS activation, increased ADH level and systemic inflammation with HF cause focal and segmental glomerulosclerosis and tubulointerstitial fibrosis in the renal parenchyma $(17,18)$.

\section{b) Right Ventricular Dilatation and Dysfunction}

Two pathogenic mechanisms causing left ventricular filling restriction are discussed in this topic. The first one is increased renal venous pressure and the other one is increased right ventricular pressure (reverse Bernheim phenomenon) (19). Increased systemic congestion due to right ventricular dysfunction independent of left ventricular EF has a negative effect on the kidney as well as other organs. There have been studies reporting that increased right atrial and central venous pressure were related with loss of renal function and, renal function recovery 
was observed with decreased systemic congestion (2026). Although it is not clear, proinflammatory cytokines secreted as a result of endothelial stretch might be responsible (27).

\section{Conventional Treatment of Heart Failure}

Diuretics, beta blockers, RAAS inhibitors, and vasodilators are the main medical treatments besides conventional approach such as salt and water restriction and quitting smoking in patients with HF. Intravenous inotrope therapy, cardiac resynchronization treatment, mechanical ventilation support, and cardiac transplantation are more aggressive approaches (28).

Diuretics are effective in relieving congestive symptoms by removing excess fluid from the body. They activate RAAS and SNS and lower systemic blood pressure and, GFR. Rebound sodium reabsorption from the tubules decreasing the efficiency of the treatment can be seen in diuretic users. Combined diuretic use is needed to prevent this condition, however, side effects such as decreased GFR, hyponatremia, and hyperkalemia may develop (2934). Although the frequency of diuretics use is high, mineralocorticoid-receptor antagonists are the only diuretic effective on survival (35).

Diuretic resistance is another problem emerging during diuretic treatments. Weight loss is not observed in approximately $20 \%$ of patients having intravenous diuretic treatments who are hospitalized because of acute decomposed $\mathrm{HF}$ and these patients are accepted as diuretic resistant. None compliance with sodium restriction, RAAS activation secondary to intravasculer volume decrease following diuretic treatment, subsequence $\mathrm{Na}-\mathrm{Cl}$ cotransporter hyperplasia and distal tubule hypertrophy, following sodium blokage in the thin ascending limb of the Henle's loop may be the mechanism contributing to diuretic resistance $(36,37)$.

Two renal replacement treatments become prominent for removal of excess fluids via ultrafiltration (UF) in $\mathrm{HF}$ patients with diuretic resistance: extracorporeal (EC) UF and PD.

\section{Extracorporeal Ultrafiltration with Hemodialysis in Heart Failure}

EC-UF with hemodialysis (HD) is thought to be an alternative or supportive to conventional treatment in HF. EC-UF has been studied in type 1 and 3 CRS patients who were admitted with acute decompensated congestive HF. In addition to this, the importance of EC-UF for type 2 and 4 CRS patients, who do not need renal replacement treatment, is less known than that for type 1 and 3 CRS patients.

There have been three large randomized studies [Ultrafiltration versus Intravenous Diuretics for Patients
Hospitalized for Acute Decompensated Congestive HF (UNLOAD), Relief for Acutely-Fluid Overloaded Patients with Decompensated Congestive HF (RAPID-CHF) and Cardiorenal Rescue Study in Acute Decompensated-HF (CARRESS-HF)] which compared diuretic treatment and EC-UF in acute decompensated HF. Mean creatinine levels in patients who were included in those studies were 1.5, 1.7 and $2.0 \mathrm{mg} / \mathrm{dL}$, respectively. One hundred eighty-eight patients were enrolled in CARRESS-HF study and more intensive diuretic treatment was administered compared to that in the other two studies (thiazide diuretic was added to the intravenous diuretic treatment after bolus administration of vasodilator and/or intravenous inotropes were given to selected cases). Weight loss via treatment was similar between the two groups $(p>0.05)$ whereas worsening in renal function and frequency of side effects were found to be significantly high in UF group ( $p=0.003$ and $p=0.003$, respectively). UNLOAD study consisted of 200 patients; weight loss was greater in UF group whereas the duration of hospitalization was found to be shorter than in other group ( $p=0.003, p=0.022$, respectively). In RAPID-CHF study that had a smaller sample size (40 patients), weight loss was found to be greater in UF group.

When the follow-up durations in the three large randomized studies, UNLOAD, RAPID-CHF, and CARRESS$\mathrm{HF}$, are analyzed there is not enough information to discuss the effect of EC-UF on long-term morbidity and mortality (90, 30, 60 days, respectively).

In the literature, there are not enough studies which compared HD and peritoneal dialysis (PD) in HF patients having renal replacement treatment because of endstage renal disease. In a study including 107.922 patients with the diagnosis of HF between 1995 and 1997, newly diagnosed end-stage renal disease patients receiving renal replacement treatment were followed up for two years. At the end of the follow-up period, the mortality rate was found to be higher in PD group than in HD patients (38). However, the PD technique was not well-developed at the time of the study; thus, patients receiving PD were prone to complications. In addition, 'icodextrin' which was especially chosen for HF patients, and low glucose degradation product solutions were not available in these years. In another study in which 'French Renal Epidemiology and Information Network Registry' data for the years between 2002 and 2008 were used, mortality rate among patients, who were followed up with HF diagnosis and were started PD and HD (933 and 3468 patients, respectively) as renal replacement treatment, when needed, was compared and survival was found to be significantly higher in HD group than in PD group (HD group 36.7 months, PD group 20.4 months; HF: 1.48) (39). However, the average age of the patients and NYHA 
stage in the PD group were higher than in HD group in this study. Furher randomized controlled trials are needed to clarify this issue.

\section{Why Peritoneal Dialysis is Chosen in the Treatment of Heart Failure?}

The use of PD in HF dates back to the 1940's (40). When PD is compared with diuretic treatment, neurohumoral activation (SNS activation, RAAS activation, endothelin, $A D H$, increase in atrial natriuretic peptide secretion), which occurs because of abrupt volume depletion with diuretics, causes vicious cycle in HF pathogenesis and increases rebound water and sodium absorption. The peritoneal dialysis does not introduce this vicious cycle because it removes the excess fluid from the body continuously and in a slow manner (41). However, there are no abrupt changes in renal hemodynamics with UF which is made slowly and controlled by PD and, by this way, PD has superiority to diuretics by preserving residual renal function (42).

Filtration in PD is isosmotic to the plasma, but fluid loss with diuretic treatment is more hypotonic $(43,44)$. When the amount of sodium removal is compared between peritoneal UF (PUF) and diuretic treatment, 130-150 $\mathrm{mmol} / \mathrm{L}$ sodium is removed by PUF and $50-100 \mathrm{mmol} / \mathrm{L}$ sodium is removed by diuretic treatment (45). In the light of this information, PUF seems to be more efficient than diuretic treatment to excrete excess fluid and sodium from the body in patients with HF.

RAAS blockers, which are proven to decrease mortality in HF patients, can not be used in some patients due to the side effects associated with hyperkalemia. Since potassium is not present in peritoneal dialysate, better potassium control can be provided and this gives opportunity to maximum congestive HF treatment which is also important with regard to survival.

Cytokines such as atrial natriuretic peptide, tumor necrosis factor- $\alpha$, interleukin- 1 , and interleukin- 6 are known to increase apoptosis of cardiac myocyte and to have negative inotropic effect. These mediators whose molecular weight ranges between 500 and 30000 Dalton can penetrate from the peritoneal membrane, by this way PD allows clearance of these agents while contributing to the support for the heart directly $(46,47)$.

Unlike extracorporeal UF, PD feasible at home and offers additional advantages in terms of cost, other advantages of PD in HF. Especially in patients with HF who are planned to undergo PD for UF the use of 'icodextrin' can provide long-term UF, reduces the number of fluid exchange, thus reducing the load on fluid exchange $(48,49)$. The advantages of PUF in HF are summarized in Table 1.

\section{Peritoneal Dialysis in Heart Failure}

\section{The Effects on Hospitalization}

$\mathrm{HF}$ is one of the diseases in which recurrent hospitalization is frequently required. It has been shown that frequent and long-term hospitalization is related with high mortality (50-54). In the CHARM study, 7572 patients with preserved or low EF were analyzed for hospitalization frequency and mortality. Mortality after hospitalization was increased [HF 3.2; 95\% confidence interval (Cl) 2.83.5] and this risk was the highest in the first month and then decreased gradually (50).

Decrease in the number of hospital admissions is quite important for protection of life quality of patient and also for national economy. Size of patient population and cost of treatment become an important part of medical expenditures of countries estimated economical cost of $\mathrm{HF}$ in the United State of America) was about 30.7 billion dollars in 2012, and this amount was expected to increase to 69.7 billion dollars in 2030 (55).

It is thought that by decreasing hospitalization rate in HF patients, life quality will get better, economical burden will get reduced, and mortality rate will decrease in long term. PUF was found to decrease the rate of hospitalization because of acute decomposed HF in several studies (56-63).

\section{Can Peritoneal Dialysis Decrease Mortality Rate?}

Mortality rates are quite high in patients followed up for HF. In a study, five-year mortality after diagnosis was found to be $52.6 \%$ for HF patients, $24.4 \%$ in patients under sixty years old, and $54.4 \%$ in patients above 80 years old (64). This rate is higher in NHYA III-IV group patients. When expected survival in this patient group and the mean age of patient who were included in the study are taken into consideration, the effect of treatment regimen which was started during follow-up is hardly determined. Besides, heterogeneity of low number patients makes difficult randomization when the presence of additional diseases

\begin{tabular}{l}
$\begin{array}{l}\text { Table 1. The advantages of peritoneal ultrafiltration in heart } \\
\text { failure treatment }\end{array}$ \\
\hline Slow and controlled in PD \\
\hline Effective in protecting residual renal functions \\
\hline Prevents rebound neurohumoral activation \\
\hline Higher amount of removed sodium besides diuretic treatment \\
\hline Eliminates cytokines that may have negative effects on the heart \\
\hline Conventional treatment is more efficient in terms of cost \\
\hline Reduces hospitalization \\
\hline Regression in heart failure related symptoms and providing increase \\
in ejection fraction \\
\hline PD: Peritoneal dialysis \\
\hline
\end{tabular}


in HF patients, number and variety of medical treatments, and the number of patients in the studies are considered. In a prospective study by Núñez et al. (65) in 2012, it was reported that the mortality rate was lower in $\mathrm{PD}$ group than in conventional treatment group $(\mathrm{HF}=0.40 ; 95 \% \mathrm{Cl}$, $0.21-0.75 ; p=0.005$ ).

There is a need for further randomized controlled studies to show the relationship between mortality and PUF precisely.

\section{How does Peritoneal Dialysis Affect Ejection Fraction or New York Heart Association Class?}

An increase in ventricular preload promotes increases in end-diastolic volume, the length of muscle fiber; leading to increase in ventricular contraction force. Than the stroke volume and cardiac output rapidly increases (Frank-Starling law). Cardiac output falls down due to decreased contractility in HF, the body increases end-diastolic volume by increasing water and sodium absorption in the framework of the Frank-Starling law to increase stroke volume. The diastolic end volume, which is increased compensatory beyond the physiological limits, is responsible for pulmonary venous congestion and congestive symptoms.

Excess fluid is cleared slowly from the body by PD without rebound mechanisms are enabled, thus, an increase in EF and a decrease in symptoms are expected according to the Frank-Starling law. One reason for the increase in EF is thought to be the removal of cardio depressant agents by PD (66). In many of these studies, the exercise capacities of HF patients were assessed by the NYHA classification and the results shows that NHYA class regresses and EF increases with PUF $(58,67-73)$.

\section{How does Peritoneal Dialysis Affect Glomerular Filtration Rate?}

An increase in serum creatinine level is observed in $21-45 \%$ of patients admitted with acute decompensated HF (74-77). Activation of RAAS and SNS due to reduced cardiac output volume and the effects of increased intraabdominal pressure (IAB) on the kidney are thought to be the causative mechanisms (24). One of the mechanisms of the effect of the IAB on the kidney is the increase of the interstitial pressure in the kidney by the reflex of the increased IAB to the renal veins resulting in renal ischemia. This condition can be similar to ischemic hepatitis occurring in HF. It has been showed that lowering IAB in HF patients improves renal function (20-26). On the other hand, unlike CARRESS, which was one of the three major studies comparing diuretic treatment with extracorporeal UF in patients with acute decompensated HF, weight loss was similar in both groups while the rate of deterioration in renal function in the extracorporeal UF group was greater than in the UF group ( $p=0.003)$ (78).

In two prospective studies, the study by Kunin et al. (63) with 37 patients and the study of Koch et al. (69) with 118 patients in which PUF and diuretic therapy used in the long-term treatment of patients with HF diagnosis were compared in the same patient groups, and the patients were observed before and after PUF, a decrease in GFR was found after P9). In many of the other studies that examined the effect of PUF on GFR, PUF was found to be ineffective on GFR $(42,56,68,79)$. In a meta-analysis including six studies with a total of 282 patients without indications of renal replacement therapy, there was no significant difference in GFR before and after PUF (80). However, the analysis of the effect of GFR before and after treatment on mortality is quite difficult because of the small and heterogeneous group of patients, the lack of controlled studies, and the high expected mortality rates in patients. In addition, single-centered, non-randomized studies including small patient groups do not seem to be sufficient to predict this issue since adjustment of the volume status in patients with HF is highly sensitive and renal ischemia and decline in GFR might be thought except for the conditions in the case of hypervolemia in which pre-renal failure is seen. Possible loss of GFR during the follow-up in these patients is another question mark. The main studies on PUF in patients with HF are summarized in Table 2.

\section{In Which Patient Group Peritoneal Ultrafiltration may be Recommended?}

Mental and physical capacity of the patient to be able to pay attention to PD independent of the disease, is essential for performing PD. UF is not recommended for routine treatment by the cardiac failure guidelines, and is recommended for a group of patients unresponsive to diuretic therapy or for those with resistant volume loading (1).

Most of the studies about the use of PUF in diureticresistant HF patients found promising results, such as a reduction in hospitalization and mortality rates, increase in $\mathrm{EF}$, and decrease in NHYA grade. In the light of the data in the literature, we recommend PUF for patients with NHYA class 3-4 who are hospitalized with the diagnosis of acute decompensated HF 2-3 times per year despite standard medical care. However, there is a need for further randomized studies in these groups of patients. The main issues about which patient group followed up with HF should be considered for PUF are summarized in Table 3. 


\section{Peritoneal Dialysis Catheter Placement Procedure and Peritoneal Dialysis Prescription}

The use of PD for UF in patients with HF is a very practical and easy-to-use treatment method for units having the necessary equipment and devices. In patient-based assessments, good results are obtained in experienced centers. One of the most important issues that should not be overlooked here is that cardiologists should have a high awareness of the fact that PD is a treatment options for refractory HF patients.

Patients should be trained appropriately about technical and hygienic details and, the role of these details should be discussed carefully with the patient.

After the patient is selected, percutaneous insertion of the PD catheter with local anesthesia may be preferred in this group of patients because of the high risk of anesthesia. Here, a different strategy can be considered for each patient, taking into account the experience of the center, the experience of the surgeon and the clinical situation of the patient. It should also be noted that this group of patients has a high rate of antiaggregants or anticoagulants use. Bleeding is less likely to occur in midline cuts, and also there are centers that do this procedure with local anesthesia and without stopping anticoagulation or antiaggregan therapy. Beginning to use the catheter immediately after insertion increases the rate of mechanical complications such as leakage from the catheter site. Stegmayr et al. (81) from Sweden proposed in their prospective study of 61 patients in which using a

\begin{tabular}{l}
$\begin{array}{l}\text { Table 3. In which conditions should peritoneal ultrafiltration } \\
\text { be recommended for patients with heart failure? }\end{array}$ \\
\hline $\begin{array}{l}\text { Despite standard medical treatment, hospitalization due to acute } \\
\text { decomposed HF over 2-3 times per year }\end{array}$ \\
\hline Despite standard medical treatment, NYHA classes 3-4 HF \\
\hline $\begin{array}{l}\text { Advanced hypotension and/or hemodynamic instability and/or no } \\
\text { need inotrope }\end{array}$ \\
\hline $\begin{array}{l}\text { Side effects observed with standard medical treatment } \\
\text { (hyperkalemia, hypotension etc.) }\end{array}$ \\
\hline Mental and physical capacity that can be done PD carefully \\
\hline $\begin{array}{l}\text { HF: Heart failure, NHYA: The New York Heart Association, PD: Peritoneal } \\
\text { dialysis }\end{array}$ \\
\hline
\end{tabular}

\section{Table 2. The studies of peritoneal ultrafiltration in heart failure}

\begin{tabular}{|c|c|c|c|c|c|c|c|}
\hline Study & $\begin{array}{l}\text { Type of } \\
\text { study, years }\end{array}$ & $\begin{array}{l}\text { Number } \\
\text { of the } \\
\text { patients }\end{array}$ & $\begin{array}{l}\text { Mean of } \\
\text { age } \\
\text { (years) }\end{array}$ & $\begin{array}{l}\text { Follow } \\
\text { up } \\
\text { period } \\
\text { (month) }\end{array}$ & Compared situations & $\begin{array}{l}\text { Effect of PD; } \\
\text { on hospitalization*, } \\
\text { on GFR }\end{array}$ & $\begin{array}{l}\text { Effect of PD; } \\
\text { on NHYA, } \\
\text { on EF, } \\
\text { on PAP }\end{array}$ \\
\hline $\begin{array}{l}\text { Courivaud } \\
\text { et al. (58) }\end{array}$ & $\begin{array}{l}\text { Retrospective } \\
\text { two center } \\
2014\end{array}$ & 126 & $72 \pm 11$ & $16 \pm 16$ & $\begin{array}{l}\text { Before and after PD } \\
\text { at the same patient } \\
\text { group }\end{array}$ & $\begin{array}{l}\text { Decrease in } \\
\text { hospitalization } \\
\text { N/A on GFR }\end{array}$ & $\begin{array}{l}\text { N/A on NHYA } \\
\text { increase in EF } \\
\text { N/A on PAP }\end{array}$ \\
\hline $\begin{array}{l}\text { Bertoli } \\
\text { et al. (56) }\end{array}$ & $\begin{array}{l}\text { Retrospective } \\
\text { multicenter } \\
2014\end{array}$ & 48 & $74 \pm 9$ & $\begin{array}{l}\text { At least } 6 \\
\text { months }\end{array}$ & $\begin{array}{l}\text { Before and after PD } \\
\text { at the same patient } \\
\text { group }\end{array}$ & $\begin{array}{l}\text { Decrease in } \\
\text { hospitalization } \\
\text { non effective on GFR }\end{array}$ & $\begin{array}{l}\text { Decrease on NYHA } \\
\text { increase in EF } \\
\text { decrease on PAP }\end{array}$ \\
\hline $\begin{array}{l}\text { Kunin } \\
\text { et al. (63) }\end{array}$ & $\begin{array}{l}\text { Prospective } \\
2013\end{array}$ & 37 & $\begin{array}{l}66 \\
\text { (median) }\end{array}$ & 42 & $\begin{array}{l}\text { Before and after PD } \\
\text { at the same patient } \\
\text { group }\end{array}$ & $\begin{array}{l}\text { Decrease in } \\
\text { hospitalization } \\
\text { decrease in GFR }\end{array}$ & $\begin{array}{l}\text { Decrease on NYHA } \\
\text { non effective on EF } \\
\text { N/A on PAP }\end{array}$ \\
\hline $\begin{array}{l}\text { Núñez } \\
\text { et al. ** (65) }\end{array}$ & $\begin{array}{l}\text { Prospective } \\
2012\end{array}$ & 62 & 74 & $\begin{array}{l}16 \\
\text { (median) }\end{array}$ & PD and control group & $\begin{array}{l}\text { Decrease in } \\
\text { hospitalization }\end{array}$ & $\begin{array}{l}\text { N/A on NHYA } \\
\text { non effective on EF } \\
\text { N/A on PAP }\end{array}$ \\
\hline $\begin{array}{l}\text { Koch } \\
\text { et al. } \\
(69)\end{array}$ & $\begin{array}{l}\text { Prospective } \\
\text { single center } \\
2012\end{array}$ & 118 & $73 \pm 11$ & $13.3 \pm 14$ & $\begin{array}{l}\text { Before and after PD } \\
\text { at the same patient } \\
\text { group }\end{array}$ & $\begin{array}{l}\text { N/A on hospitalization } \\
\text { decrease in GFR }\end{array}$ & $\begin{array}{l}\text { Decrease on NYHA } \\
\text { non effective on EF } \\
\text { non effective on PAP }\end{array}$ \\
\hline $\begin{array}{l}\text { Sánchez } \\
\text { et al. (68) }\end{array}$ & $\begin{array}{l}\text { Prospective } \\
\text { single center } \\
2010\end{array}$ & 17 & $64 \pm 9$ & $15 \pm 9$ & $\begin{array}{l}\text { Before and after PD } \\
\text { at the same patient } \\
\text { group }\end{array}$ & $\begin{array}{l}\text { Decrease in } \\
\text { hospitalization } \\
\text { non effective on GFR }\end{array}$ & $\begin{array}{l}\text { Decrease on NYHA } \\
\text { non effective on EF } \\
\text { decrease on PAP }\end{array}$ \\
\hline $\begin{array}{l}\text { Nakayama } \\
\text { et al. (42) }\end{array}$ & $\begin{array}{l}\text { Prospective } \\
\text { single center } \\
2010\end{array}$ & 12 & $81 \pm 6$ & $\begin{array}{l}26.5 \\
\text { (median) }\end{array}$ & $\begin{array}{l}\text { Before and after PD } \\
\text { at the same patient } \\
\text { group }\end{array}$ & $\begin{array}{l}\text { N/A on hospitalization } \\
\text { non effective on GFR }\end{array}$ & $\begin{array}{l}\text { Decrease on NYHA } \\
\text { non effective on EF } \\
\text { N/A on PAP }\end{array}$ \\
\hline $\begin{array}{l}\text { Gotloib } \\
\text { et al. (47) }\end{array}$ & $\begin{array}{l}\text { Prospective } \\
\text { single center } \\
2005\end{array}$ & 20 & $65 \pm 7$ & $19.8 \pm 7.3$ & $\begin{array}{l}\text { Before and after PD } \\
\text { at the same patient } \\
\text { group }\end{array}$ & $\begin{array}{l}\text { Decrease in } \\
\text { hospitalization } \\
\text { N/A on GFR }\end{array}$ & $\begin{array}{l}\text { Decrease in NYHA } \\
\text { N/A on EF } \\
\text { N/A on PAP }\end{array}$ \\
\hline \multicolumn{8}{|c|}{$\begin{array}{l}\text { *Admission to acute decomposed heart failure } \\
\text { ** Mortality was reduced with peritoneal dialysis } \\
\text { PD: Peritoneal dialysis, GFR: Glomerular filtration }\end{array}$} \\
\hline
\end{tabular}


3-bag suture technique for catheter insertion, as a way to prevent leakage even if peritoneal dialysis was immediately initiated (81). However, if possible, we still suggest a twoweek waiting period after catheter insertion.

Patient's preference as well as the clinical situation determines primarily the choice of UF for night or day and instrumental or manual methods. It has been shown that the rate of infection was lower with the use of single change instead of multiple changes $(42,47,68,82)$. Especially in patients with residual renal function, the use of 'icodextrin', which provides long-term UF and allows single change, appears to be a more practical and appropriate option.

Because fluid passage through 'icodextrin' is mostly from pores, the so-called 'sodium sieving' phenomenon that can be seen in glucose-based fluids using aquaporin channels is not observed and also the patient is not exposed to glucose toxicity $(56,83)$.

\section{Conclusion}

In conclusion, PD is an alternative therapy that can be used to reduce cardiac volume burden in patients who do not respond well to standard treatments and require frequent hospitalization. It is a cheap, practical and convenient method when appropriate treatment is scheduled to appropriate patient at the appropriate center.

\section{Authorship Contributions}

Concept: T.E.Ş., S.Ö. Design: E.C. Data Collection or Processing: T.E.Ş. Analysis or Interpretation: T.E.Ş., E.C. Literature Search: T.E.Ş. Writing: T.E.Ş., S.Ö.

Conflict of Interest: No conflict of interest was declared by the authors.

Financial Disclosure: The authors declared that this study received no financial support.

\section{References}

1. Ponikowski P, Voors AA, Anker SD, et al. 2016 ESC Guidelines for the Diagnosis and Treatment of Acute and Chronic Heart Failure. Rev Esp Cardiol 2016;69:1167.

2. Mosterd A, Hoes AW. Clinical epidemiology of heart failure. Heart 2007;93:1137-46.

3. Bleumink GS, Knetsch AM, Sturkenboom MC, et al. Quantifying the heart failure epidemic: prevalence, incidence rate, lifetime risk and prognosis of heart failure The Rotterdam Study. Eur Heart J 2004;25:1614-9.

4. Ceia F, Fonseca C, Mota T, et al. Prevalence of chronic heart failure in Southwestern Europe: the EPICA study. Eur J Heart Fail 2002;4:531-9.
5. Değertekin M, Erol C, Ergene O, et al. [Heart failure prevalence and predictors in Turkey: HAPPY study]. Turk Kardiyol Dern Ars 2012;40:298-308.

6. Elsayed EF, Tighiouart H, Griffith J, Kurth T, Levey AS, Salem D. Cardiovascular disease and subsequent kidney disease. Arch Intern Med 2007;167:1130-6.

7. Sarnak MJ, Levey AS, Schoolwerth AC, Coresh J, Culleton B, Hamm LL. Kidney disease as a risk factor for development of cardiovascular disease: a statement from the American Heart Association Councils on Kidney in Cardiovascular Disease, High Blood Pressure Research, Clinical Cardiology, and Epidemiology and Prevention. Circulation 2003;108:2154-69.

8. Smith $\mathrm{GL}$, Lichtman $\mathrm{JH}$, Bracken MB, et al. Renal impairment and outcomes in heart failure: systematic review and metaanalysis. J Am Coll Cardiol 2006;47:1987-96.

9. Ezekowitz J, McAlister FA, Humphries $\mathrm{KH}$, et al. The association among renal insufficiency, pharmacotherapy, and outcomes in 6,427 patients with heart failure and coronary artery disease. J Am Coll Cardiol 2004;44:1587-92.

10. Hillege HL, Girbes $A R$, de Kam PJ, et al. Renal function, neurohormonal activation, and survival in patients with chronic heart failure. Circulation 2000;102:203-10.

11. Heywood JT, Fonarow GC, Costanzo MR, et al. High prevalence of renal dysfunction and its impact on outcome in 118,465 patients hospitalized with acute decompensated heart failure: a report from the ADHERE database. J Card Fail 2007;13:422-30.

12. McAlister FA, Ezekowitz J, Tonelli M, Armstrong PW. Renal insufficiency and heart failure: prognostic and therapeutic implications from a prospective cohort study. Circulation 2004;109:1004-9.

13. Chan EJ, Dellsperger KC. Cardiorenal Syndrome: The Clinical Cardiologists' Perspective. Cardiorenal Med 2011;1:13-22.

14. Ronco C, McCullough P, Anker SD, et al. Cardio-renal syndromes: report from the consensus conference of the acute dialysis quality initiative. Eur Heart J 2010;31:703-11.

15. Schrier RW. Blood urea nitrogen and serum creatinine: not married in heart failure. Circ Heart Fail 2008;1:2-5.

16. Sarraf M, Schrier RW. Cardiorenal syndrome in acute heart failure syndromes. Int J Nephrol 2011;2011:293938.

17. Torre-Amione G. Immune activation in chronic heart failure. Am J Cardiol 2005;95:3-8.

18. Cruz DN, Schmidt-Ott KM, Vescovo G, et al. Pathophysiology of cardiorenal syndrome type 2 in stable chronic heart failure: workgroup statements from the eleventh consensus conference of the Acute Dialysis Quality Initiative (ADQI). Contrib Nephrol 2013;182:117-36.

19. Alpert JS. The effect of right ventricular dysfunction on left ventricular form and function. Chest 2001;119:1632-3.

20. Damman K, van Deursen VM, Navis G, Voors AA, van Veldhuisen DJ, Hillege HL. Increased central venous pressure is associated with impaired renal function and mortality in a 
broad spectrum of patients with cardiovascular disease. J Am Coll Cardiol 2009;53:582-8.

21. Damman $\mathrm{K}$, Voors $A A$, Hillege $H L$, et al. Congestion in chronic systolic heart failure is related to renal dysfunction and increased mortality. Eur J Heart Fail 2010;12:974-82.

22. Mullens W, Abrahams Z, Francis GS, et al. Importance of venous congestion for worsening of renal function in advanced decompensated heart failure. J Am Coll Cardiol 2009;53:589-96.

23. Mullens W, Abrahams Z, Francis GS, Taylor DO, Starling RC, Tang WH. Prompt reduction in intra-abdominal pressure following large-volume mechanical fluid removal improves renal insufficiency in refractory decompensated heart failure. J Card Fail 2008;14:508-14.

24. Mullens W, Abrahams Z, Skouri HN, et al. Elevated intraabdominal pressure in acute decompensated heart failure: a potential contributor to worsening renal function? J Am Coll Cardiol 2008;51:300-6.

25. Nohria A, Hasselblad V, Stebbins A, Pauly DF, Fonarow GC, Shah M. Cardiorenal interactions: insights from the ESCAPE trial. J Am Coll Cardiol 2008;51:1268-74.

26. Verhaert D, Mullens W, Borowski $A$, et al. Right ventricular response to intensive medical therapy in advanced decompensated heart failure. Circ Heart Fail 2010;3:340-6.

27. Sinkeler SJ, Damman K, van Veldhuisen DJ, Hillege H, Navis G. A re-appraisal of volume status and renal function impairment in chronic heart failure: combined effects of pre-renal failure and venous congestion on renal function. Heart Fail Rev 2012;17:263-70.

28. Adler ED, Goldfinger JZ, Kalman J, Park ME, Meier DE. Palliative care in the treatment of advanced heart failure. Circulation 2009; 120:2597-606.

29. De Vecchis R, Ariano C, Esposito C, Giasi A, Cioppa C, Cantatrione S. In right or biventricular chronic heart failure addition of thiazides to loop diuretics to achieve a sequential blockade of the nephron is associated with increased risk of dilutional hyponatremia: results of a case-control study. Minerva Cardioangiol 2012;60:517-29.

30. Ellison $\mathrm{DH}$. The physiologic basis of diuretic synergism: its role in treating diuretic resistance. Ann Intern Med 1991;114:88694.

31. Knauf $H$, Mutschler E. Sequential nephron blockade breaks resistance to diuretics in edematous states. J Cardiovasc Pharmacol 1997;29:367-72.

32. Fallick C, Sobotka PA, Dunlap ME. Sympathetically mediated changes in capacitance: redistribution of the venous reservoir as a cause of decompensation. Circ Heart Fail 2011;4:669-75.

33. Zeidel ML, Kikeri D, Silva P, Burrowes M, Brenner BM. Atrial natriuretic peptides inhibit conductive sodium uptake by rabbit inner medullary collecting duct cells. J Clin Invest 1988;82:1067-74.
34. Janssen WM, de Zeeuw D, van der Hem GK, de Jong PE. Atrial natriuretic peptide-induced decreases in renal blood flow in man: implications for the natriuretic mechanism. Clin Sci 1989;77:55-60.

35. Pitt B, Zannad F, Remme WJ, et al. The effect of spironolactone on morbidity and mortality in patients with severe heart failure. Randomized Aldactone Evaluation Study Investigators. N Engl J Med 1999;341:709-17.

36. Wilcox CS, Mitch WE, Kelly RA, et al. Response of the kidney to furosemide. I. Effects of salt intake and renal compensation. J Lab Clin Med 1983;102:450-8.

37. Ellison DH, Velazquez $\mathrm{H}$, Wright FS. Adaptation of the distal convoluted tubule of the rat. Structural and functional effects of dietary salt intake and chronic diuretic infusion. J Clin Invest 1989;83:113-26.

38. Stack AG, Molony DA, Rahman NS, Dosekun A, Murthy B. Impact of dialysis modality on survival of new ESRD patients with congestive heart failure in the United States. Kidney Int 2003;64:1071-9.

39. Sens F, Schott-Pethelaz AM, Labeeuw M, Colin C, Villar E; REIN Registry. Survival advantage of hemodialysis relative to peritoneal dialysis in patients with end-stage renal disease and congestive heart failure. Kidney Int 2011;80:970-7.

40. Schneierson SJ. Continuous peritoneal irrigation in the treatment of intractable edema of cardiac origin. Am J Med Sci 1949;218:76-9.

41. Ellison DH. Diuretic therapy and resistance in congestive heart failure. Cardiology 2001;96:132-43.

42. Nakayama M, Nakano H, Nakayama M. Novel therapeutic option for refractory heart failure in elderly patients with chronic kidney disease by incremental peritoneal dialysis. J Cardiol 2010;55:49-54.

43. Johnson DW, Agar J, Collins J, et al. Recommendations for the use of icodextrin in peritoneal dialysis patients. Nephrology (Carlton) 2003;8:1-7

44. Costanzo MR, Guglin ME, Saltzberg MT, et al. Ultrafiltration versus intravenous diuretics for patients hospitalized for acute decompensated heart failure. J Am Coll Cardiol 2007;49:675-83.

45. Musetti C, Ciurlino D, Bertoli SV. Free water transport measured by double mini-PET may be increased by higher glucose exposure in peritoneal dialysis. Perit Dial Int 2012;32:211-5.

46. Ross EA, Kazory A. Ultrafiltration therapy for cardiorenal syndrome: physiologic basis and contemporary options. Blood Purif 2012;34:149-57.

47. Gotloib L, Fudin R, Yakubovich M, Vienken J. Peritoneal dialysis in refractory end-stage congestive heart failure: a challenge facing a no-win situation. Nephrol Dial Transplant 2005;20(Suppl 7):vii32-6.

48. Ho-dac-Pannekeet MM, Schouten N, Langendijk MJ, et al. Peritoneal transport characteristics with glucose polymer based dialysate. Kidney Int 1996;50:979-86. 
49. Ota K, Akiba T, Nakao T, Nakayama M, Maeba T, Park MS. Peritoneal ultrafiltration and serum icodextrin concentration during dialysis with $7.5 \%$ icodextrin solution in Japanese patients. Perit Dial Int 2003;23:356-61.

50. Solomon SD, Dobson J, Pocock S, et al. Influence of nonfatal hospitalization for heart failure on subsequent mortality in patients with chronic heart failure. Circulation 2007;116:1482-7.

51. Michalsen A, König G, Thimme W. Preventable causative factors leading to hospital admission with decompensated heart failure. Heart 1998;80:437-41.

52. Opasich C, Rapezzi C, Lucci D, et al. Precipitating factors and decision-making processes of short-term worsening heart failure despite "optimal" treatment (from the IN-CHF Registry). Am J Cardiol 2001;88:382-7.

53. Tsuyuki RT, McKelvie RS, Arnold JM, et al. Acute precipitants of congestive heart failure exacerbations. Arch Intern Med 2001;161:2337-42.

54. Lee DS, Austin PC, Stukel TA, et al. "Dose-dependent" impact of recurrent cardiac events on mortality in patients with heart failure. Am J Med 2009;122:162-9.

55. Heidenreich PA, Albert NM, Allen LA, et al. Forecasting the impact of heart failure in the United States: a policy statement from the American Heart Association. Circ Heart Fail 2013;6:606-19.

56. Bertoli SV, Musetti C, Ciurlino D, et al. Peritoneal ultrafiltration in refractory heart failure: a cohort study. Perit Dial Int 2014;34:64-70.

57. Paniagua R, Orihuela O, Ventura MD, et al. Echocardiographic, electrocardiographic and blood pressure changes induced by icodextrin solution in diabetic patients on peritoneal dialysis. Kidney Int Suppl 2008:125-30.

58. Courivaud C, Kazory A, Crépin T, et al. Peritoneal dialysis reduces the number of hospitalization days in heart failure patients refractory to diuretics. Perit Dial Int 2014;34:100-8.

59. Tormey V, Conlon PJ, Farrell J, Horgan J, Walshe JJ. Long-term successful management of refractory congestive cardiac failure by intermittent ambulatory peritoneal ultrafiltration. QJM 996;89:681-3.

60. Ryckelynck JP, Lobbedez T, Valette B, et al. Peritoneal ultrafiltration and refractory congestive heart failure. Adv Perit Dial 1997;13:93-7.

61. Elhalel-Dranitzki M, Rubinger D, Moscovici $A$, et al. CAPD to improve quality of life in patients with refractory heart failure. Nephrol Dial Transplant 1998;13:3041-2.

62. Cnossen TT, Kooman JP, Konings CJ, Uszko-Lencer $\mathrm{NH}$, Leunissen KM, van der Sande FM. Peritoneal dialysis in patients with primary cardiac failure complicated by renal failure. Blood Purif 2010;30:146-52.

63. Kunin M, Arad M, Dinour D, Freimark D, Holtzman EJ. Peritoneal dialysis in patients with refractory congestive heart failure: potential prognostic factors. Blood Purif 2013;35:285-94.

64. Gerber Y, Weston SA, Redfield MM, et al. A contemporary appraisal of the heart failure epidemic in Olmsted County, Minnesota, 2000 to 2010. JAMA Intern Med 2015;175:9961004.

65. Núñez J, González M, Miñana G, et al. Continuous ambulatory peritoneal dialysis and clinical outcomes in patients with refractory congestive heart failure. Rev Esp Cardiol (Engl Ed) 2012;65:986-95.

66. Zemel D, Imholz AL, de Waart DR, Dinkla C, Struijk DG, Krediet RT. Appearance of tumor necrosis factor-alpha and soluble TNF-receptors I and II in peritoneal effluent of CAPD. Kidney Int 1994;46:1422-30.

67. Ryckelynck JP, Lobbedez T, Valette $B$, et al. Peritoneal ultrafiltration and treatment-resistant heart failure. Nephrol Dial Transplant 1998;13(Suppl 4):56-9.

68. Sánchez JE, Ortega T, Rodríguez C, et al. Efficacy of peritoneal ultrafiltration in the treatment of refractory congestive heart failure. Nephrol Dial Transplant 2010;25:605-10.

69. Koch M, Haastert B, Kohnle M, et al. Peritoneal dialysis relieves clinical symptoms and is well tolerated in patients with refractory heart failure and chronic kidney disease. Eur J Heart Fail 2012;14:530-9.

70. Sotirakopoulos NG, Kalogiannidou IM, Tersi ME, Mavromatidis KS. Peritoneal dialysis for patients suffering from severe heart failure. Clin Nephrol 2011;76:124-9.

71. Hébert MJ, Falardeau M, Pichette $V$, et al. Continuous ambulatory peritoneal dialysis for patients with severe left ventricular systolic dysfunction and end-stage renal disease. Am J Kidney Dis 1995;25:761-8.

72. Kagan A, Rapoport J. The role of peritoneal dialysis in the treatment of refractory heart failure. Nephrol Dial Transplant 2005;20(Suppl 7):28-31.

73. Takane H, Nakamoto $H$, Arima $H$, et al. Continuous ambulatory peritoneal dialysis is effective for patients with severe congestive heart failure. Adv Perit Dial 2006;22:141-6.

74. Chittineni H, Miyawaki N, Gulipelli S, Fishbane S. Risk for acute renal failure in patients hospitalized for decompensated congestive heart failure. Am J Nephrol 2007;27:55-62.

75. Krumholz HM, Chen YT, Vaccarino V, et al. Correlates and impact on outcomes of worsening renal function in patients $>$ or $=65$ years of age with heart failure. Am J Cardiol 2000;85:1110-3.

76. Smith GL, Vaccarino V, Kosiborod M, et al. Worsening renal function: what is a clinically meaningful change in creatinine during hospitalization with heart failure? J Card Fail 2003;9:13-25.

77. Forman DE, Butler J, Wang Y, et al. Incidence, predictors at admission, and impact of worsening renal function among 
patients hospitalized with heart failure. J Am Coll Cardiol 2004;43:61-7.

78. Bart BA, Goldsmith SR, Lee $\mathrm{KL}$, et al. Ultrafiltration in decompensated heart failure with cardiorenal syndrome. $\mathrm{N}$ Engl J Med 2012;367:2296-304.

79. Diez Ojea B, Rodriguez Suarez C, Vidau P, et al. [Peritoneal dialyisis role in heart failure treatment, experience in our center]. Nefrologia 2007;27:605-11.

80. Lu R, Muciño-Bermejo MJ, Ribeiro LC, et al. Peritoneal dialysis in patients with refractory congestive heart failure: a systematic review. Cardiorenal Med 2015;5:145-56.
81. Stegmayr BG, Sperker W, Nilsson CH, Degerman C, Persson SE. Few outflow problems with a self-locating catheter for peritoneal dialysis: A randomized trial. Medicine (Baltimore) 2015; 94(48):e2083

82. Ruhi Ç, Koçak H, Yavuz A, Süleymanlar G, Ersoy FF. Use of peritoneal ultrafiltration in the elderly refractory congestive heart failure patients. Int Urol Nephrol 2012;44:963-9.

83. Struijk DG. Volume status in CAPD and APD: does treatment modality matter and is more always better? Perit Dial Int 2007;27:641-4. 